Assiut University web-site: www.aun.edu.eg

\title{
AFLATOXIN M RESIDUES IN RUMINANTS MILK IN LUXOR GOVERNORATE
}

\author{
TOHAMEYA A. HUSSIEN ${ }^{1}$; ABDEL-LATIEF SH. SEDDEK ${ }^{1}$ and DIEFY A. SALEM ${ }^{2}$ \\ ${ }^{1}$ Forensic Medicine and Toxicology Department, Faculty of Veterinary Medicine, \\ South Valley University \\ ${ }^{2}$ Forensic Medicine and Toxicology Department, Faculty of Veterinary Medicine, Assiut University
}

Received: 18 January 2017; $\quad$ Accepted: 6 March 2017

\begin{abstract}
This study was carried out to investigate aflatoxin $\mathrm{M}_{1}\left(\mathrm{AFM}_{1}\right)$ in raw milk of ruminant animals (cows, buffaloes, sheep, goats and camels) in Luxor Governorate to know any of these species milk is contaminated by the toxin and to determine its concentration to avoid its harmful effect on consumers' health. A total number of 165 milk samples were collected from various villages at the main three cities in Luxor Governorate (Esna, Armant and Luxor cities) in winter season 2015-2016 (11 milk samples from each species per city) and the samples had been analyzed by ELIZA test kits. The obtained results revealed that $\mathrm{AFM}_{1}$ levels were lower than previous surveys in Egypt. The percent of positive milk samples in all species were 32.7, 58.18 and 56.36\% from Esna, Armant and Luxor cities, respectively. $\mathrm{AFM}_{1}$ could not be detected in sheep and goat samples from Esna, camel and goat samples from Armant and camel samples from Luxor city. Overall, the percent of positive milk samples in all cities from Luxor Governorate were 66.6\% (22 out 33) in cows, 63.6\% (21 out 33) in buffaloes, $15.2 \%$ (5 out 33 ) in camels, $66.7 \%$ (22 out 33) in sheep and 33.3\% (11 out 33) in goats. AFM $_{1}$ mean values in milk samples of cows, buffaloes, camels, sheep and goats were 4.518, 1.951, 0.091, 2.966 and $0.582 \mathrm{ng} / \mathrm{l}$ respectively. The highest mean value of $\mathrm{AFM}_{1}(10.953 \mathrm{ng} / \mathrm{l})$ was found in cow's milk from Armant followed by sheep milk from Luxor $(6.811 \mathrm{ng} / \mathrm{l})$ then buffaloes milk from Armant $(4.005 \mathrm{ng} / \mathrm{l})$. The highest value of $\mathrm{AFM}_{1}(14.307 \mathrm{ng} / \mathrm{l}) \mathrm{was}$ detected in cow's milk from Armant city followed by $(13.177 \mathrm{ng} / \mathrm{l})$ in buffaloes milk from Luxor. Concerning the health hazard for consumers, no milk samples exceeded the permissible limits of the US regulations (500ng/l) and the European Commission regulations (50ng/l), while all positive samples of raw milk are exceeding Egyptian regulations (free from $\mathrm{AFM}_{1}$ ). In conclusion, high prevalence of $\mathrm{AFM}_{1}$ in milk from Luxor Governorate indicated that the contamination of raw milk is very high and this due to the contamination of feedstuffs of these animals with $\mathrm{AFB}_{1}$. Because of these findings, we need to survey aflatoxins incidence and levels in feedstuffs and milk during all seasons of the year in this areas.
\end{abstract}

Key words: Aflatoxin $M_{1}$, Residues, Ruminants Milk, Luxor Governorate.

\section{INTRODUCTION}

Mycotoxins are products or metabolites produced by fungi which are harmful to other's life. In order to allow mycotoxins production, three factors should be involved: (1) The presence of mycotoxinogenic fungi, (2) The presence of substrate, and (3) the optimal environmental conditions eg. optimal temperature and relative humidity for example aflatoxins are mostly present in Africa because of the optimum temperature and high relative humidity (Phillips, 1999). Therefore, these factors lead to variations in the geographical distribution of mycotoxins, mycotoxicosis lead to

Corresponding author: Dr. DIEFY A. SALEM

E-mail address: diefy_salem@yahoo.com

Present address: Forensic Medicine and Toxicology Department,

Faculty of Veterinary Medicine, Assiut University various hazard effects in animals starting with emaciation, loss of production and ending with mortality (Kiessling et al., 1984). Moreover, mycotoxicosis has public health importance because of transmission to humane via milk, eggs, and meat (Manal et al., 2012).

Aflatoxins (AFs) are a major class of mycotoxins (Creppy, 2002). Aflatoxin B1 (AFB $)_{1}$, aflatoxin $\mathrm{B}_{2}$ $\left(\mathrm{AFB}_{2}\right)$, aflatoxin $\mathrm{G}_{1}\left(\mathrm{AFG}_{1}\right)$ and aflatoxin $\mathrm{G}_{2}\left(\mathrm{AFG}_{2}\right)$ are the major classes of AFs (Sweeney and Dobson, 1998). Prolonged drought, high temperatures, substrate composition, storage time and storage conditions play an important role in fungal growth and the synthesis of AFs (Stack and Carlson, 2003). Aflatoxin $B_{1}$ is the most toxic, carcinogenic, teratogenicand mutagenic of AFs (Iqbal et al., 2010). $\mathrm{AFB}_{1}$ is a group 1 carcinogen by the International Agency for Research on Cancer (IARC, 2002; Iqbal et al., 2014)' Aflatoxin $\mathrm{M}_{1}\left(\mathrm{AFM}_{1}\right)$ is a hydroxylated 
metabolite of $\mathrm{AFB}_{1}$ (Asi et al., 2012). $\mathrm{AFM}_{1}$ is excreted in milk in the mammary glands of both humans and lactating animals (Fallah et al., 2009). $0.3-6.2 \%$ of $\mathrm{AFB}_{1}$ is converted into metabolized $\mathrm{AFM}_{1}$ and excreted in milk, depending on the genetics of the animals, seasonal variation, the milking process and the environmental conditions (Unusan, 2006). Presence of $\mathrm{AFM}_{1}$ in milk and milk products is a health damage because every age group regularly consumed milk and milk products in their daily diet (Fallah et al., 2009). International Agency for Research on Cancer (IARC) has positioned $\mathrm{AFM}_{1}$ with $\mathrm{AFB}_{1}$ as a Group 1 carcinogen (IARC, 2002). $\mathrm{AFM}_{1}$ is very stable at high temperatures (Oruc, 2006).

The goal of the present work is to determine the prevalence of $\mathrm{AFM}_{1}$ in raw milk samples collected from various ruminant species (cows, buffalos, sheep, goats and camels), in winter season 2015-2016 at various geographical areas from Luxor Governorate (Esna, Armant and Luxor cities) to estimate its levels to evaluate health risks for human consumers.

\section{MATERIALS AND METHODS}

\section{Sampling:}

In order to study prevalence of $\mathrm{AFM}_{1}$ and its level in raw milk of different animal species in Luxor Governorate, a total number of 165 samples were collected from some villages at the three main cities (Esna, Armant and Luxor). The samples were collected from five species of ruminant animals (Cows, Buffaloes, Camels, Sheep and Goats). The total number of samples from each city was 55 samples (11 samples from every species). Milk samples were randomly collected during the duration between December 2015 and February 2016 (winter season). The samples were kept frozen till analysis.

\section{Methods:}

Aflatoxin $\mathrm{M}_{1}$ was measured in milk samples using a commercially available ELISA test kit (REAGEN ${ }^{\mathrm{TM}}$, Product Code: RNM 98001, United states).

\footnotetext{
Aflatoxin $M_{1}$ ELISA Test Kit

$\mathrm{AFM}_{1}$ ELISA Test Kit is competitive enzyme immunoassay for the quantitative analysis of $\mathrm{AFM}_{1}$ in milk and milk powder. The sample can be directly used for the ELISA plate without extraction and with high sensitivity $(0.005 \mathrm{ng} / \mathrm{g}$ or ppb) and low detection limit in milk $(0.005 \mathrm{ppb})$. The method is based on a competitive colorimetric ELISA assay. The $\mathrm{AFM}_{1}$ antibody has been coated in the plate wells. During the analysis, sample is added to the wells for incubation. After washing the plate, the $\mathrm{AFM}_{1}-$ horseradish peroxidase $\left(\mathrm{AFM}_{1}-\mathrm{HRP}\right)$ conjugate is added to the wells for incubation. If the $\mathrm{AFM}_{1}$ residue is present in the sample, it will compete for $\mathrm{AFM}_{1}$ antibody, thereby preventing the $\mathrm{AFM}_{1}-\mathrm{HRP}$
}

from binding to the antibody attached to the well. The resulting color intensity, after addition of the HRP substrate (TMB), has an inverse relationship with the aflatoxin $M_{1}$ residue concentration in the sample.

$\mathrm{AFM}_{1}$ in milk samples was measured according to the instructions of the manufacturer using the following standards $(0.0,0.005,0.015,0.03,0.09$ and $0.27 \mathrm{ng} / \mathrm{ml}$ ). Briefly, $200 \mathrm{uL}$ of each $\mathrm{AFM}_{1}$ standard and sample were added in duplicate into different wells. The plate was incubated for 60 minutes in the dark at room temperature $\left(20-25^{\circ} \mathrm{C}\right)$. The plate was washed 3 times with $250 \mathrm{uL}$ of $1 \mathrm{X}$ wash solution. After the last wash, the plate was inverted and gently taped the plate dry on paper towels. Immediately after plate washings, $100 \mathrm{uL}$ of $\mathrm{AFM}_{1}$-HRP conjugate was added to each well. The plat incubated for 15 minutes at room temperature. Washing procedure was repeated again and $100 \mathrm{uL}$ of TMB substrate was added to each well. After incubation for 15 minutes at room temperature (20-25 $\dot{\mathrm{C}}), 100 \mathrm{uL}$ of stop solution was added to each well to stop the enzyme reaction. $\mathrm{AFM}_{1}$ was measured on micro plate reader (Stat Fax 2100 Reader, USA) with $450 \mathrm{~nm}$ wavelength against the air blank.

\section{Aflatoxin $M_{1}$ concentration calculations:}

A standard curve can be constructed by plotting the mean relative absorbance (\%) obtained from each reference standard against its concentration in $\mathrm{ng} / \mathrm{ml}$ on a logarithmic curve.

Relative absorbance $(\%)=$ absorbance standard (or sample) $\times 100 /$ absorbance zero standard

\section{Statistical analysis:}

The statistical software package SPSS version 16 was employed. Data are presented as mean \pm standard deviation (SD) and the range (minimum to maximum).

\section{RESULT}

The obtained results were presented in Tables (1, 2, 3 and 4) and Figure 1. The data showed that milk samples from all species were contaminated with different values and percent of $\mathrm{AFM}_{1}$ which could not be detected in sheep and goat samples from Esna, and also in camel and goat samples from Armant and camel samples from Luxor city. The percent of positive samples represented $32.7,58.18$ and $56.36 \%$ of all tested species in Esna, Armant and Luxor cities, respectively. Overall, the highest mean value of $\mathrm{AFM}_{1}(10.953 \mathrm{ng} / \mathrm{l})$ was found in cow's milk from Armant followed by sheep milk from Luxor (6.811) then buffaloes milk from Armant also (4.005 ng/l). The highest value of aflatoxin $\mathrm{M}_{1}(14.307 \mathrm{ng} / \mathrm{l})$ was detected in cow's milk from Armant city followed by (13.177 ng/l) in buffaloes milk from Luxor. 
Results of $\mathrm{AFM}_{\mathbf{1}}$ in milk samples from Esna city were reported in Table 1 and Figure1. Cow's milk contained the highest concentration of $\mathrm{AFM}_{1}$ followed by camel's milk then buffalo's milk. AFM 1 was not detected in sheep and goat's milk from Esna.

Results of $\mathrm{AFM}_{1}$ in milk samples from Armant city were reported in Table 2 and Figure1. AFM 1 was detected in all species milk except camels and goats.
Cow's milk was contained the highest mean values followed by buffalo's and sheep milk.

Results of $\mathrm{AFM}_{1}$ in all milk samples from Luxor Governorate were reported in Table 4 and Figure 1. $\mathrm{AFM}_{1}$ mean value in cow's milk was the highest followed by sheep then buffalos and finally camel's milk.

Table (1): $\mathrm{AFM}_{1}$ concentration (ng/l) in milk of different animal species from Esna city.

\begin{tabular}{lccccc}
\hline & \multicolumn{5}{c}{ Animal Species } \\
\cline { 2 - 6 } Parameter & Cow & Buffalo & Camel & Sheep & Goat \\
\hline Mean & 2.464 & 0.171 & 0.274 & 0.000 & 0.000 \\
\hline S. D. & 1.583 & 0.197 & 0.341 & 0.000 & 0.000 \\
\hline Minimum & 0.0 & 0.0 & 0.0 & 0.000 & 0.000 \\
\hline Maximum & 3.388 & 0.376 & 0.753 & 0.000 & 0.000 \\
\hline Percent of positive & 72.7 & 45.5 & 45.5 & 0 & 0 \\
samples & $(8 / 11)$ & $(5 / 11)$ & $(5 / 11)$ & $(0 / 11)$ & $(0 / 11)$ \\
\hline Exceeding ER & 8 & 5 & 5 & 0 & 0 \\
\hline Exceeding EC & 0 & 0 & 0 & 0 & 0 \\
\hline Exceeding US FDA & 0 & 0 & 0 & 0 & 0 \\
\hline
\end{tabular}

ER: Egyptian regulations, (1990), the limit in milk is $0 \mathrm{ng} / \mathrm{L}$.

EC: European Commission, (2006), the limit in milk is $50 \mathrm{ng} / \mathrm{L}$.

US FDA: US FDA, (2011), the limit in milk is 500 ng/LFDA: Food and Drug Administration.

Table (2): $\mathrm{AFM}_{1}$ concentration (ng/l) in milk of different animal species in Armant city.

\begin{tabular}{lccccc}
\hline & \multicolumn{5}{c}{ Animal Species } \\
\cline { 2 - 6 } Parameter & Cow & Buffalo & Camel & Sheep & Goat \\
\hline mean & 10.953 & 4.005 & 0.000 & 2.088 & 0.000 \\
\hline S. D. & 4.150 & 1.158 & 0.000 & 1.109 & 0.000 \\
\hline Minimum & 0.000 & 2.635 & 0.000 & 0.753 & 0.000 \\
\hline Maximum & 14.307 & 6.777 & 0.000 & 3.0120 & 0.000 \\
\hline Percent of positive & 90.9 & 100 & 0 & 100 & 0 \\
samples & $(10 / 11)$ & $(11 / 11)$ & $(0 / 11)$ & $(11 / 11)$ & $(0 / 11)$ \\
\hline Exceeding ER & 10 & 11 & 0 & 11 & 0 \\
\hline Exceeding EC & 0 & 0 & 0 & 0 & 0 \\
\hline Exceeding US FDA & 0 & 0 & 0 & 0 & 0 \\
\hline
\end{tabular}

ER: Egyptian regulations, (1990), the limit in milk is $0 \mathrm{ng} / \mathrm{L}$.

EC: European Commission, (2006), the limit in milk is $50 \mathrm{ng} / \mathrm{L}$.

US FDA: US FDA, (2011), the limit in milk is 500 ng/LFDA: Food and Drug Administration. 
Table (3): $\mathrm{AFM}_{1}$ concentration (ng/l) in milk of different animal species in Luxor city.

\begin{tabular}{lccccc}
\hline & \multicolumn{3}{c}{ Animal Species } \\
\cline { 2 - 6 } Parameter & Cow & Buffalo & Camel & Sheep & Goat \\
\hline Mean & 0.137 & 1.677 & 0.000 & 6.811 & 1.746 \\
\hline S. D. & 0.190 & 3.914 & 0.000 & 2.198 & 2.043 \\
\hline Minimum & 0.000 & 0.000 & 0.000 & 0.753 & 0.376 \\
\hline Maximum & 0.376 & 13.177 & 0.000 & 8.659 & 4.894 \\
\hline Percent of positive & 36.4 & 45.5 & 0 & 100 & 100 \\
samples & $(4 / 11)$ & $(5 / 11)$ & $(0 / 11)$ & $(11 / 11)$ & $(11 / 11)$ \\
\hline Exceeding ER & 4 & 5 & 0 & 11 & 11 \\
\hline Exceeding EC & 0 & 0 & 0 & 0 & 0 \\
\hline Exceeding US FDA & 0 & 0 & 0 & 0 & 0 \\
\hline
\end{tabular}

ER: Egyptian regulations, (1990), the limit in milk is $0 \mathrm{ng} / \mathrm{L}$.

EC: European Commission, (2006), the limit in milk is $50 \mathrm{ng} / \mathrm{L}$.

US FDA: US FDA, (2011), the limit in milk is 500 ng/LFDA: Food and Drug Administration

Table (4): $\mathrm{AFM}_{1}$ concentration (ng/l) in milk of different animal species in Luxor Governorate.

\begin{tabular}{lccccc}
\hline & \multicolumn{5}{c}{ Animal Species } \\
\cline { 2 - 6 } Parameter & Cow & Buffalo & Camel & Sheep & Goat \\
\hline Mean & 4.518 & 1.951 & 0.091 & 2.966 & 0.582 \\
\hline S. D. & 5.335 & 2.79 & 0.231 & 3.204 & 1.415 \\
\hline Minimum & 0.000 & 0.000 & 0.000 & 0.000 & 0.000 \\
\hline Maximum & 14.307 & 13.177 & 0.753 & 8.659 & 4.894 \\
\hline Percent of positive & 66.7 & 63.6 & 15.2 & 66.7 & 33.3 \\
samples & $(22 / 33)$ & $(21 / 33)$ & $(5 / 33)$ & $(22 / 33)$ & $(11 / 33)$ \\
\hline Exceeding ER & 22 & 21 & 5 & 22 & 11 \\
\hline Exceeding EC & 0 & 0 & 0 & 0 & 0 \\
\hline Exceeding US FDA & 0 & 0 & 0 & 0 & 0 \\
\hline
\end{tabular}

ER: Egyptian regulations, (1990), the limit in milk is $0 \mathrm{ng} / \mathrm{L}$.

EC: European Commission, (2006), the limit in milk is $50 \mathrm{ng} / \mathrm{L}$.

US FDA: US FDA, (2011), the limit in milk is 500 ng/LFDA: Food and Drug Administration

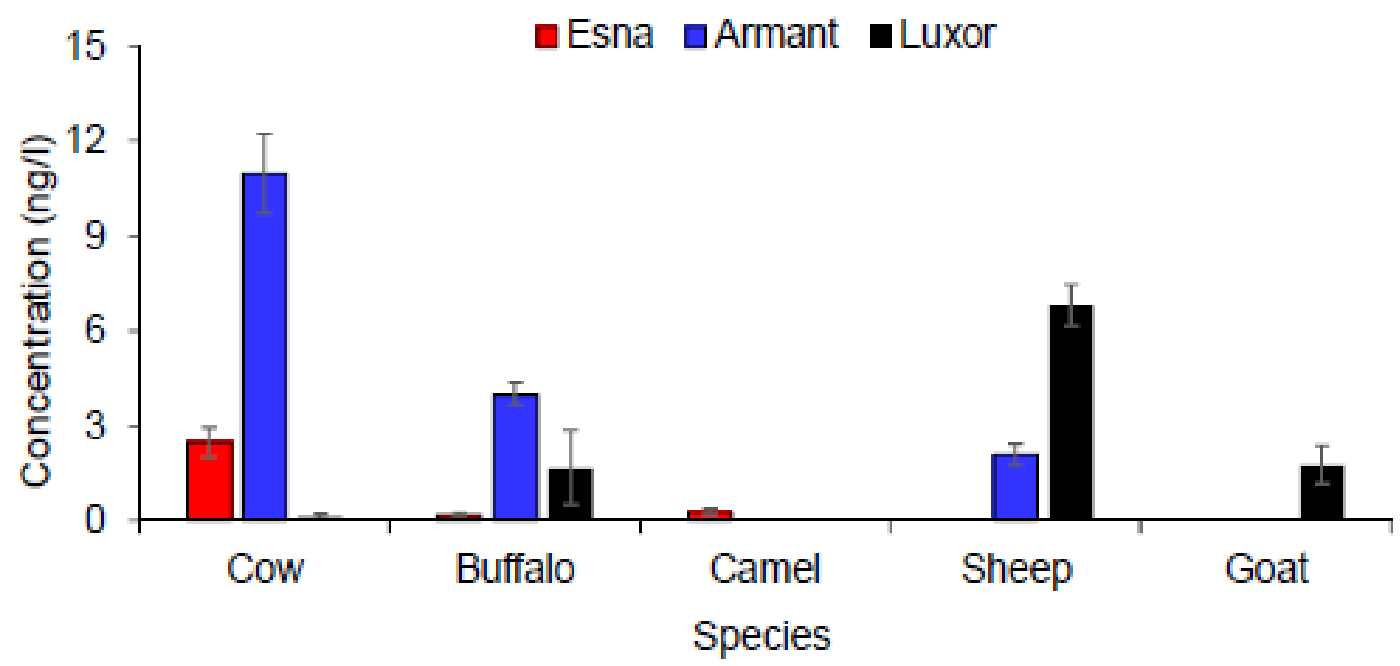

Figure 1: $\mathrm{AFM}_{1}$ mean values (ng/l) in different animal species and cities of Luxor Governorate. 


\section{DISCUSSION}

Mycotoxins are toxic secondary metabolites of fungal origin and contaminate agricultural commodities before or under post-harvest conditions. They are mainly produced by fungi as the Aspergillus, Penicillium and Fusarium. Mycotoxins affect a broad range of agricultural products including cereals, cereal based foods, dried fruits, wine, milk, coffee beans, meat products, which are the sources of the economies of many developing countries (Shephard et al., 2012). They are one of the most important naturally occurring toxins in various foods stand in inproper conditions. Meat, eggs, milk, and other palatable products from animals that consume mycotoxins contaminated feed are additional sources of potential exposure to these toxins (Report on Carcinogens, 2009). Milk is a highly nutritive food containing many macro- and micronutrients that are essential for the growth and maintenance of human health. The health of human populations is often reflected in the condition of their food-producing ecosystems. Moreover, the implementation of food regulations may be directly linked with the quantity and quality of available food. Therefore, consumers from developing countries, especially from rural areas, face problems related to food security and food safety because they depend on locally produced foods (Marroquín-Cardona et al., 2014).

Many international studies reported $\mathrm{AFM}_{1}$ with variable levels and percent in milk and milk products (Fallah et al., 2009; Bilandzic et al., 2010; Buket et al., 2010; Golge, 2014; Iqbal et al., 2014; Oluwafemi et al., 2014 and Bilandzic et al., 2015. In Egypt, There are limited surveys for $\mathrm{AFM}_{1}$ in milk were carried in some governorates in lower and upper Egypt (Salem, 2002; Motawee et al., 2004a and 2004b; Motawee et al., 2009; Amer and Ibrahim, 2010; Ghareeb et al., 2013; Shaker and El Sharkawy, 2014 and Abdallah, 2016). They found $\mathrm{AFM}_{1}$ in milk with wide difference in its occurrence and levels depending on the geographical location and the environmental conditions of the area under research.

The present study showed that $\mathrm{AFM}_{1}$ levels were lower than previous surveys in Egypt. The percent of positive milk samples in all species were 32.7, 58.18 and $56.36 \%$ from Esna, Armant and Luxor cities, respectively. $\mathrm{AFM}_{1}$ could not be detected in sheep and goat samples from Esna, camel and goat samples from Armant and camel samples from Luxor city. The highest mean value of $\mathrm{AFM}_{1}(10.953 \mathrm{ng} / \mathrm{l})$ was found in cow's milk from Armant followed by sheep milk from Luxor $(6.811 \mathrm{ng} / \mathrm{l})$ then buffaloes milk from Armant also (4.005 ng/l). The highest value of aflatoxin $\mathrm{M}_{1}(14.307 \mathrm{ng} / \mathrm{l})$ was detected in cow's milk from Armant city followed by $(13.177 \mathrm{ng} / \mathrm{l})$ in buffaloes milk from Luxor.
Overall, the percent of positive milk samples in all cities from Luxor Governorate were $66.6 \%$ (22 out 33 ) in cows, $63.6 \%$ (21 out 33) in buffaloes, $15.2 \%$ (5 out 33 ) in camels, $66.7 \%$ (22 out 33 ) in sheep and $33.3 \%$ (11 out 33 ) in goats. $\mathrm{AFM}_{1}$ mean values in milk samples of cows, buffaloes, camels, sheep and goats were $4.518,1.951,0.091,2.966$ and $0.582 \mathrm{ng} / \mathrm{l}$ respectively.

The levels specially in cow and buffalo milk were lower than observed in Egyptian governorates although the prevalence were nearly similar when comparing the levels of $\mathrm{AFM}_{1}$ in milk detected in this study with previous research (Salem, 2002; Motawee et al., 2004a and 2004b; Motawee et al., 2009; Amerand Ibrahim, 2010; Ghareeb et al., 2013; Shaker and El Sharkawy, 2014 and Abdallah, 2016).

Amer and Ibrahim (2010) found that $38 \%$ of raw milk samples collected from Alexandria city (north of Egypt) were positive for $\mathrm{AFM}_{1}$ with a mean concentration of $49.74 \pm 17.26 \mathrm{ng} / \mathrm{L}$ and all positive samples were exceeding the Egyptian regulations, while $52.6 \%$ of examined samples were exceeding European Commission regulation (50 ng/l or $\mathrm{Kg}$ ) (European Commission Regulation, 2006); and all of them are with in the US regulations $(500 \mathrm{ng} / \mathrm{l}$ or $\mathrm{Kg}$ ) (FDA, 2011).

Ghareeb et al. (2013) reported that the occurrence of $\mathrm{AFM}_{1}$ in milk samples from Qena province was $97.92 \%$ (47 samples out of 48 samples were positive) and the mean level of $\mathrm{AFM}_{1}$ was $62.81 \pm 32.10 \mathrm{ng} / \mathrm{L}$ ranging from $2 \mathrm{ng} / \mathrm{L}$ to $110 \mathrm{ng} / \mathrm{L}$. The level of $\mathrm{AFM}_{1}$ in $53.19 \%$ of raw milk samples was higher $(79.85 \pm 17.30 \mathrm{ng} / \mathrm{L})$ than the maximum tolerance limit (50 $\mathrm{ng} / \mathrm{L})$ established by European Union (European Commission Regulation, 2006). According to the Egyptian regulations (1990), the amount of $\mathrm{AFM}_{1}$ in the positive samples (47 from 48 samples, $97.92 \%$ ) goes beyond the regulations, suggesting that the contamination of raw milk is very high, probably due to the higher contamination of cattle feeds with $\mathrm{AFB}_{1}$ in the study area.

Shaker and El Sharkawy, (2014) found that all milk samples from Sohag and Assiut cities were positive for $\mathrm{AFM}_{1}$. The mean concentration of $\mathrm{AFM}_{1}$ in raw buffalo milk from Sohag was $64.49 \pm 16.8 \mathrm{ng} / \mathrm{L}$, with an average of $123.27 \mathrm{ng} / \mathrm{L} ; 86.5 \%$ contained $\mathrm{AFM}_{1}$ at levels higher than the maximum permissible limit of $50 \mathrm{ng} / \mathrm{L}$ set by the EU regulations (European Commission Regulation, 2006). In Assiut, the mean concentration of $\mathrm{AFM}_{1}$ in raw buffalo milk was 130.6 $\pm 29.9 \mathrm{ng} / \mathrm{L}$, with an average of $250.79 \mathrm{ng} / \mathrm{L}$. All tested samples from Assiut were above the MRL set by the EU regulations (European Commission Regulation, 2006); but only one sample at the 500 ng/L maximum set by the FDA (2011).

Recently, Abdallah et al. (2016) detected $\mathrm{AFM}_{1}$ in all the samples analyzed in a limited survey on raw milk 
from local shops in Assiut. The range was (0.02-0.19 $\mu \mathrm{g} / \mathrm{kg}$ ) were lower than the incidence of AFM1 reported by Shaker and El Sharkawy, (2014) and higher than Salem's study (Salem, 2002) in which up to $0.015 \mu \mathrm{g} / \mathrm{kg}$ in Assiut city was detected by ELISA. Their results showed also that 14 samples (70\%) were above the maximum permissible level in the European Union which is $0.05 \mu \mathrm{g} / \mathrm{kg}$ (4). All samples were above the Egyptian regulation in 1990 (Egyptian Regulations, 1990) (milk sold in Egyptian markets should be free of $\mathrm{AFM}_{1}$ ).

The obtained results showed that the occurrence of $\mathrm{AFM}_{1}$ were $66.7 \%(22 / 33)$ in cows and sheep milk, $63.6 \%(21 / 33)$ in buffalo's milk, 33.3\% (11/33) in goat's milk and $15.2 \%$ (5/33 samples) in camel's milk, which are similar or lower than reported previously mentioned.

Occurrence and level $\mathrm{AFM}_{1}$ in the raw milk produced in Luxor Governorate are lower compared with raw milk produced in a similar study (Motawee et al., 2009) in the Ismailia in Egypt, during the summers of 2003 and 2004. They examined 175 milk samples (50 cows, 50 buffalos, 50 goats and 25 camels) and found that all samples were positive for $\mathrm{AFM}_{1}$. Most milks $(80 \%, 74 \%, 66 \%$ and $52 \%$ of the camel, goat, cow and buffalo milks, respectively) were below the European Union maximum of $\mathrm{AFM}_{1} \leq 50 \mathrm{ng} / \mathrm{L}$ and all milk samples were $<500 \mathrm{ng} / \mathrm{L}$.

$\mathrm{AFM}_{1}$ was detected in camel's milk from Esna city only with low level $0.274 \pm 0.341 \mathrm{ng} / \mathrm{L}$ (and prevalence $(5 / 33$ samples) in comparison with that reported by Balata and Bahout (1996), who reported $\mathrm{AFM}_{1}$ levels in Egyptian camel milk up to $850 \mathrm{ng} / \mathrm{L}$ and by (Motawee et al., 2009), who found $\mathrm{AFM}_{1}$ levels in camel milk up to $250 \mathrm{ng} / \mathrm{L}$.

Several countries have set acceptable limits of $\mathrm{AFM}_{1}$ in milk and its by-products to exclude the possible toxicity for humans. In the European Union, the maximum limit of $\mathrm{AFM}_{1}$ in liquid milk and dried or processed milk products is set at 50ng/L (European Commission Regulation, 2006). In USA, the level of $\mathrm{AFM}_{1}$ in milk should not be higher than $500 \mathrm{ng} / \mathrm{Kg}$ (FDA, 2011). In Egypt, the Ministry of Health recognized that fluid milk and dairy products should be free from $\mathrm{AFM}_{1}$ (Egyptian Regulations, 1990).

Concerning the health hazard for consumers, all positive samples of raw milk are exceeding Egyptian regulations (free from $\mathrm{AFM}_{1}$ ), while no milk samples exceeded the permissible limits of the US regulations (500ng/l) and the European Commission regulations (50ng/l).

Prandini et al. (2009) reported that more than half of the milk samples are contaminated by $\mathrm{AFM}_{1}$. The presence of $\mathrm{AFM}_{1}$ inmilk and dairy products is an important issue, especially for developing countries. $\mathrm{AFM}_{1}$ is stable in kashar cheese for over 60 days and in traditional white pickled cheese for over 90 days, also the toxin is stable during cheese storage and ripening (Govaris et al., 2002). The mean level of $\mathrm{AFM}_{1}$ in milk of Punjab, Pakistanwas $0.323 \mathrm{mg} / \mathrm{L}$ (Sadia et al., 2012). The levels of AFs in food vary from 0 to $50 \mathrm{mg} / \mathrm{kg}$ (FAO/WHO, 2009). The levels of $\mathrm{AFM}_{1}$ in milk and dairy products in Ismailia, Egypt were $0.05 \mathrm{ug} / \mathrm{L}$ in Buffalo, $0.05 \mathrm{ug} / \mathrm{L}$ in Cow, $0.05 \mathrm{ug} / \mathrm{l}$ in Goat and $0.05 \mathrm{ug} / \mathrm{l}$ in Camel (Motawee et al., 2009). High rate of contamination were found in raw cow milk from North African countries where the level of $\mathrm{AFM}_{1}$ ranging between 30 and $3130 \mathrm{ng} / \mathrm{L}$ (Elgerbi et al., 2004). In Korea, the concentration of $\mathrm{AFM}_{1}$ in raw milk was $57 \mathrm{ng} / \mathrm{L}$ (Kim et al., 2000). In Croatia, in $98.4 \%$ of raw milk samples, levels of $\mathrm{AFM}_{1}$ were less than the maximum acceptance level of the European Union (Bilandzic et al., 2010). $\mathrm{AFM}_{1}$ concentration in cow's milk samples was 108.2 ng/L in Nigeria (Oluwafemi et al., 2014).

$\mathrm{AFM}_{1}$ has been detected in milk, which cannot be removed from milk by pasteurization, ultra-high temperature heat processing or other methods (Iqbal et al., 2010). The $\mathrm{AFM}_{1}$ molecule cannot be inactivated in the dairy industry (Fallah et al., 2011). $\mathrm{AFM}_{1}$ concentration in milk is related to seasonal variations, and AFM1 contents in raw milk are the highest during cold seasons (Bilandzic et al., 2015).

The level of $\mathrm{AFM}_{1}$ in milk samples during winter is significantly higher than summer in all lactating species i.e., dairy cow, buffalo, goat, sheep and camel in Pakistan (Asi et al., 2012). AFM 1 concentration in milk during winter exceeded the European Union limit level, with the maximal level of $1101 \mathrm{ng} / \mathrm{L}$ in Adana province of Turkey (Golge, 2014).

In conclusion, high prevalence of $\mathrm{AFM}_{1}$ in milk from Luxor Governorate indicated that the contamination of raw milk is very high and this due to the contamination of feedstuffs of these animals with $\mathrm{AFB}_{1}$. Because of these findings, we need to survey aflatoxins incidence and levels in feedstuffs and milk during all seasons of the year in this areas.

\section{REFERENCES}

Abdallah, M.F.; Kllıçarslan, B.; Girgin, G. and Baydar, T. (2016): Determination of aflatoxin M1 in raw milk samples from Assiut city, Egypt. $38^{\text {th }}$ Mycotoxin Workshop, Berlin May 2-4/2016, Society for Mycotoxin Research.

Amer, A.A. and Ibrahim, M.A.E. (2010): Determination of aflatoxin M1 in raw milk and traditional cheeses retailed in Egyptian markets. Journal of Toxicology and Environmental Health Sciences 2: 50-53.

Asi, M.R.; Iqbal, S.Z.; Ari no, A. and Hussain, A. (2012): Effect of seasonal variations and lactation times on aflatoxin M1 contamination in milk of different species from Punjab, Pakistan. Food Control, 25, 34-38. 
Balata, MA. and Bahout, AA. (1996): Aflatoxin M1 in camel's milk. Vet. Med. J. Giza-Egypt 44(2A): 109-111

Bilandzic, N.; Varenina, I. and Solomun, B. (2010): Aflatoxin M1 in raw milk in Croatia. Food Control, 21(9), 1279-1281.

Bilandzic, N.; Varenina, I.; Kolanovi,_C.B.S.; Bo_zi_c.Đ.; Đoki,_C.M. and Sedak, M. et al. (2015): Monitoring of aflatoxin M1 in raw milk during fourseasons in Croatia. Food Control, 54, 331-337.

Buket, Er.; Demirhan, B.; Onurdag, FK. and Yentur, G. (2010): Determination of aflatoxin M1 in milk and white cheese consumed in Ankara region, Turkey. J. Anim. Vet. Adv. 9:1780-4.

Creppy, E.E. (2002): Update of survey, regulation and toxic effects of mycotoxins in Europe. Toxicology Letters, 127, 19-28.

Egyptian Regulations. (1990): Maximum Limits for Mycotoxin in Foods. Part L Aflatoxins E.S. 1875-1990. Egyptian Organization for Standardization and Quality Control.

Elgerbi, A.M.; Aidoo, K.E.; Candlish, A.A. and Tester, R.F. (2004): Occurrence of aflatoxin M1 in randomly selected North African milk and cheese samples. Food Additives and Contaminants, 21(6), 592-597.

European Commission Regulation (2006): (EC) No. 1881/2006 of 19 December 2006. Setting maximum levels for certain contaminants in foodstuffs. Off J European Union 364:5-24 L077: 1-13

Fallah, A.A.; Jafari, T.; Fallah, A. and Rahnama, $M$. (2009): Determination of aflatoxin M1 levels in Iranian white and cream cheese. Food and Chemical Toxicology, 47, 1872-1875.

Fallah, A.A.; Rahnama, M.; Jafari, T. and SaeiDehkordi, S.S. (2011): Seasonal variation of aflatoxin M1 contamination in industrial and traditional Iranian dairy products. Food Control, 22, 1653-1656.

FAO/WHO. (2009): Evaluation of certain food additives. Sixty-ninth report of the Joint FAO/WHO Expert Committee on food additives. Geneva: World Health Organization (WHO Technical Report Series, No. 952 http://whqlibdoc. who. int/trs/ WHO_TRS_952_eng.pdf.

FDA, U.S. (2011): Guidance for Industry: Action Levels for Poisonous or Deleterious Substances in Human Food and Animal Feed. Food and Drug Administration; (April 2011) 20/04/2011. Available from: http:// www.fda.gov/ Food/Guidance Compliance Regulatory Information/ Guidance Documents/ Chemical Contaminants and Pesticides/ ucm 077969. htm.

Ghareeb, K.; Elmalt, L.M.; Awad, W.A. and Böhm, J. (2013): Prevalence of aflatoxin M1 in raw milk produced in tropical state (Qena, Egypt) and imported milk powder. J. Vet. Anim. Sci. Vol. 3 No. (1-2): 1-4.

Golge, O. (2014): A survey on the occurrence of aflatoxin M1 in raw milk produced in Adana province of Turkey. Food Control, 45, 150155.

Govaris, A.; Roussi, V.; Koidis, P.A. and Botsoglou, N.A. (2002): Distribution and stability of aflatoxin M1 during production and storage of yogurt. Food Additives and Contaminants, 19(11), 1043-1050.

IARC, International Agency for Research on Cancer. (2002): Aflatoxins. In IARC monograph on the evaluation of carcinogenic risk to humans, World Health Organization Vol. 82. IARC, Lyon, France.

Iqbal, S.Z.; Asi, M.R. and Jinap, S. (2014): A survey of aflatoxin M1 contamination in milk from urban and rural farmhouses of Punjab, Pakistan. Food Additives and Contaminants Part-B, 7(1), 17-20.

Iqbal, S.Z.; Paterson, R.R.M.; Bhatti, I.A. and Asi, M.R. (2010): Survey of aflatoxins in chilies from Pakistan produced in rural, semi-rural and urban environments. Food Additive and Contaminants Part-B, 3(4), 268-274.

Kiessling, K.H.; Pettersson, H.; Sandholm, K. and Olsen, M. (1984): Metabolism of aflatoxin, ochratoxin, zearalenone, and three tricothecenes by intact rumen fluid, rumen protozoa, and rumen bacteria.Appl. Environ. Mircobiol., 47, 1070-1073.

Kim, E.K.; Shon, D.H.; Ryu, D.; Park, J.W.; Hwand, H.J. and Kim, Y.B. (2000): Occurrence of aflatoxin $\mathrm{M} 1$ in Korean dairy products determined by ELISA and HPLC. Food Additives and Contaminants, 17, 59-64.

Manal M. Zaki; El-Midany, S.A.; Shaheen, H.M. and Laura Rizzi (2012): Journal of Toxicology and Environmental Health Sciences Vol. 4(1), pp. 13-28, 5 January.

Marroquín-Cardona, A.G.; Johnson, N.M.; Phillips, T.D. and Hayes, A.W. (2014): Mycotoxins in a changing global environment: a review. Food and Chemical toxicology, 69, 220-230.

Motawee, MM.; Meyer, M. and Bauer, J. (2004a): Incidence of aflatoxin M1 and B1 in raw milk and some dairy products in Damietta. Egypt $\mathbf{J}$ Agric Sci Mansoura Univ.; 29:711-8.

Motawee, MM.; Meyer, M. and Bauer, J. (2004b): Occurrence of aflatoxin M1 and B1 in milk and some milk products in Mansoura. Egypt $\mathbf{J}$ Agric Sci Mansoura Univ. 29:719-25.

Motawee, M.M.; Bauer, J. and McMahon, D.J. (2009): Survey of aflatoxin M1 in cow, goat, Buffalo and Camel milks in Ismailia-Egypt. Bulletin of Environmental Contamination and Toxicology, 83, 766-769.

Oluwafemi, F.; Badmos, A.O.; Kareem, S.O.; Ademuyiwa, O. and Kolapo, A.L. (2014). 
Survey of aflatoxin M1 in cows' milk from free-grazing cows in Abeokuta, Nigeria. Mycotoxin Res, 30, 207-211.

Oruc, H.H.; Cibik, R.; Yikmaz, E. and Kalkanli, O. (2006): Distribution and stability of aflatoxin M1 during processing and ripening of traditional white pickled cheese. Food Additives and Contaminants, 23(2), 190-195.

Phillips, T.D. (1999): Dietary clay in the chemoprevention of aflatoxin induced disease. Toxicol. Sci. 52:118-126.

Prandini, A.; Transini, G.; Sigolo, S.; Filippi, L.; Laporta, M. and Piva, G. (2009): On the occurrence of aflatoxin M1 in milk and dairy products. Food and Chemical Toxicology, 47, 984-991.

Report on Carcinogens. (2009): $11^{\text {th }}$ US Department of Health and Human Services, Public Health Service, National Toxicology Program. Pursuant to Section 301(b) (4) of the Public Health Service Act as Amended by Section 262, PL 95-622.Aflatoxins CAS No. 1402-682.

Sadia, A.; Jabbar, M.A.; Deng, Y.; Hussain, E.A.; Riffat, S. and Naveed, S. et al. (2012): A survey of aflatoxin M1 in milk and sweets of Punjab, Pakistan. Food Control, 26, 235-240.
Salem, D.A. (2002): Natural Occurance of Aflatoxins in Feedstuffs and Milk of Dairy Farms in Assiut Porvince, Egypt. Wien Tierarztl Monatsschr, 89: 86-91.

Shaker, E.M. and El sharkawy, E.E. (2014): Occurrence and the level of contamination of aflatoxin M1 in raw, pasteurized, and UHT buffalo milk consumed in Sohag and Assiut, Upper Egypt. Journal of Environmental and Occupational Science, 2014, 3: 136-140.

Shephard, G.S.; Berthiller, E.; Burdaspal, P.A.; Crews, C.; Jonker, M.A.; Krska, R.; MacDonald, S.; Malone, R.J.; Maragos, C.; Sabino, M.; Solfrizzo, M.; Van Egmond, H.P. and Whitaker, T.B. (2012): World Mycotoxin Journal 5:3-30

Stack, J. and Carlson, M. (2003): NF571 Aspergillus flavus and aflatoxins in corn, plant diseases, C-18, field crops. Lincoln: Historical Materials from University of Nebraska.

Sweeney, MJ. and Dobson, ADW. (1998): Mycotoxin production by Aspergillus, Fusarium, and Pencillium species. International Journal of Food Microbiology 43, 141-158.

Unusan, N. (2006): Occurrence of aflatoxin M1 in UHT milk in Turkey. Food and Chemical Toxicology, 44(11), 1897-190.

بقايا الأفلاتوكسين م, في ألبان المجترات في محافظة الأقصر

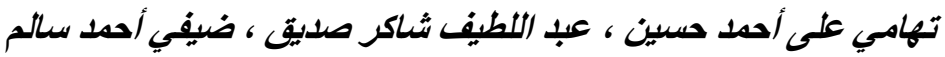

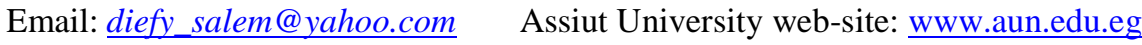

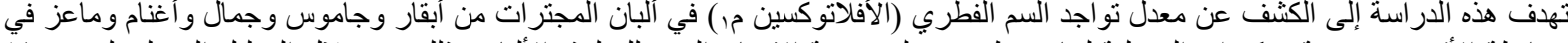

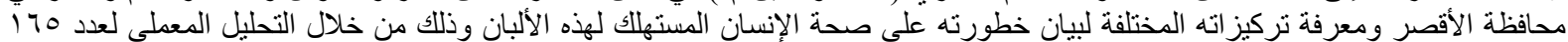

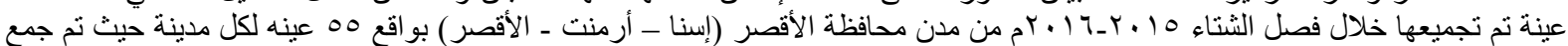

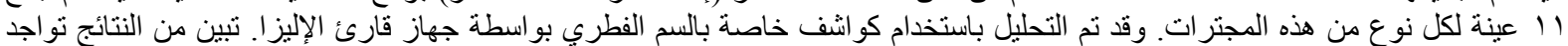

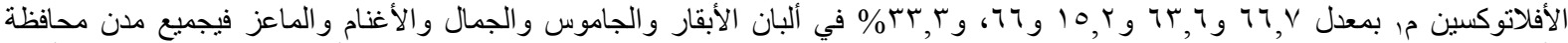

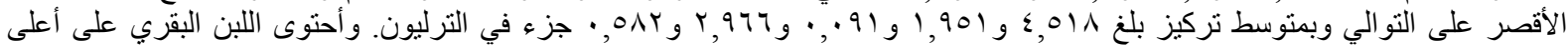

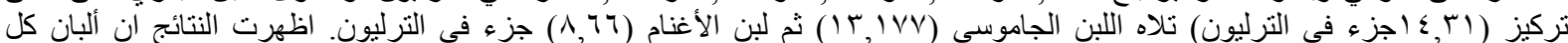

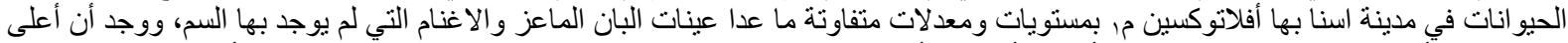

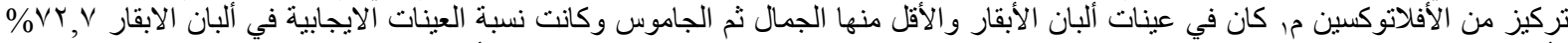

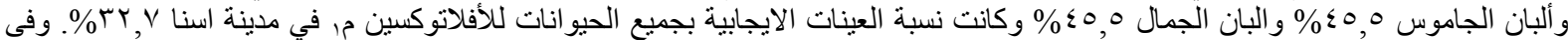

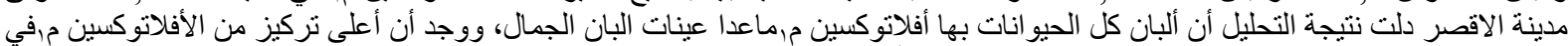

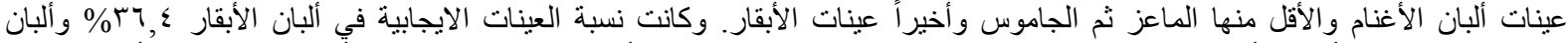

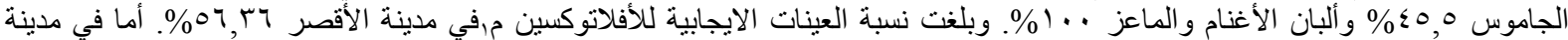

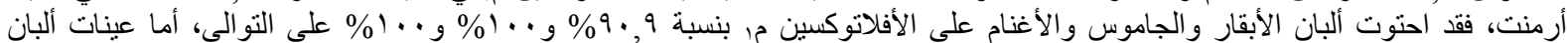

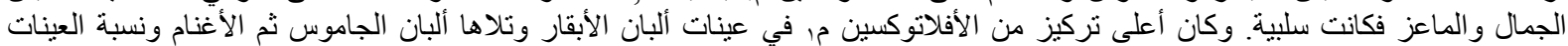

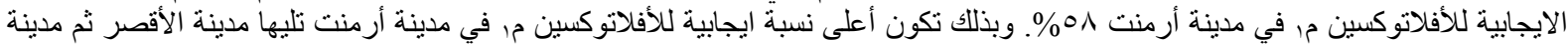

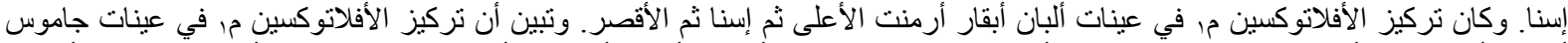

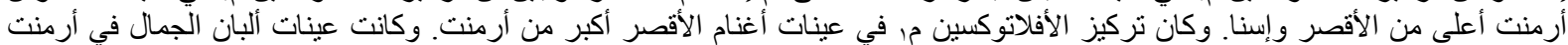

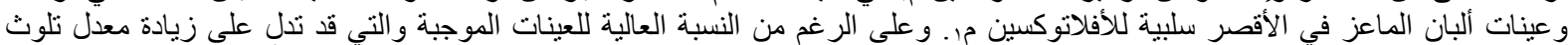

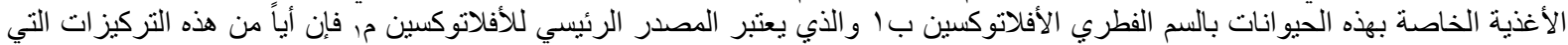

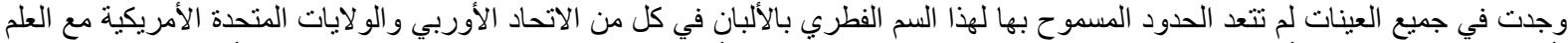

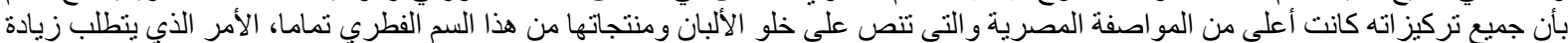

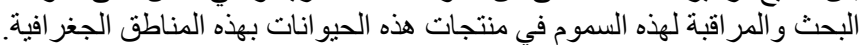

